\title{
Influence of Different Levels Phosphorous and Zinc on Yield and Yield Attributes of Mung Bean [Vigna Radiata L.].
}

\author{
Farhan Ahmad*, Junaid Ahmad, Minhaj Ali Shah, Sarmad Iqbal, Zahid Mehmood and Waseem Abbas \\ Department of Agronomy, Faculty of Crop production, University of Agriculture Peshawar, Pakistan \\ Submitted: July 27, 2018; Published: August 07, 2018 \\ *Corresponding author: Farhan Ahmad, Department of Agronomy, Faculty of Crop production, University of Agriculture Peshawar, Pakistan, Tel: \\ 3159198887; Email: farhan.syk@gmail.com
}

\begin{abstract}
To study the influence of different levels of phosphorous and zinc on yield and yield attributes of mung bean (BARI Mug 6) an experiment was conducted at Agronomy Research Farm, Peshawar, during kharif season of 2017. Four phosphorus (P) levels $\left(0,15,20\right.$ and $25 \mathrm{~kg}^{\mathrm{P}}$ ha $\left.{ }^{-1}\right)$ and three zinc $(\mathrm{Zn})$ levels $\left(0,1.5\right.$ and $\left.4 \mathrm{~kg} \mathrm{Zn} \mathrm{ha-1}^{-1}\right)$ were used in the study. The results of the study shown that stover and seed yield of mung bean improved with increasing phosphorus and zinc levels up to positive level. For instance, of Phosphorous the significant maximum stover yield $\left(2.59 \mathrm{t} \mathrm{ha}^{-1}\right)$ and seed yield $\left(1.53 \mathrm{tha}^{-1}\right)$ were obtained with the treatment P3 $\left(25 \mathrm{~kg} \mathrm{P} \mathrm{ha}^{-1}\right)$ and the significant minimum stover yield $\left(2.08 \mathrm{t} \mathrm{ha} \mathrm{a}^{-1}\right)$ and minimum seed yield $\left(1.43 \mathrm{t} \mathrm{ha}^{-1}\right)$ were obtained with the treatment P0 $\left(0 \mathrm{~kg} \mathrm{P} \mathrm{ha}^{-1}\right)$. In case of Zn the significant maximum stover yield $(2.77$ $\left.\mathrm{t} \mathrm{ha}^{-1}\right)$ and maximum seed yield $\left(1.77 \mathrm{t} \mathrm{ha}^{-1}\right)$ were obtained with the treatment $\mathrm{Zn} 2\left(4 \mathrm{~kg} \mathrm{Zn} \mathrm{ha}{ }^{-1}\right)$ and the significant minimum stover yield $(2.19$ $\left.\mathrm{t} \mathrm{a}^{-1}\right)$ and minimum seed yield $\left(1.38 \mathrm{t} \mathrm{ha}^{-1}\right)$ were achieved with the treatment $\mathrm{Zn} 0(0 \mathrm{~kg} \mathrm{Zn} \mathrm{ha-1})$. The significant maximum number of branch plant ${ }^{-1}(3.32)$, taller plant $(53.45 \mathrm{~cm})$, seed yield $\left(1.94 \mathrm{t} \mathrm{ha}^{-1}\right)$, yield supporting factors as number of pods plant $\mathrm{t}^{-1}(20.89), 1000$ seeds weight (45.66 g) and number of seeds pod $^{-1}(12.98)$ were achieved with the treatment combination P2Zn2 (20 kg P ha-1 4 kg Zn ha-1).
\end{abstract}

Abbreviations: BARI: Bangladesh Agricultural Research Institute; WHO: World Health Organization; RCBD: Randomized Complete Block Design; NARC: National Agricultural Research Institute; LSD: Least Significant Difference

\section{Introduction}

Mung bean (Vigna radiata L.) is an excellent source of easily digestible protein and is one of the chief pulse crop [1]. It belongs to the family Leguminosae. BARI mug 6 is a yield potential, innovated by Bangladesh Agricultural Research Institute (BARI) and contribute well in crop rotation between two different cereal crops [2]. In Bangladesh, daily consumption of pulses is only $14.30 \mathrm{~g}$ capita-l day ${ }^{-1}$, while $45 \mathrm{~g}$ capita-l day ${ }^{-1}$ for a balanced diet suggested by World Health Organization (WHO). Mung bean is rich source of vegetable protein [3]. It is considered as poor man's meat containing almost triple amount of protein as compared to rice. It contains $50.4 \%$ carbohydrates, $3.5-4.5 \%$ fibers, $1-3 \%$ fat and $4.5-5.5 \%$ ash, while phosphorus and calcium are 367 and $132 \mathrm{mg}$ per 100 grams of seed, respectively [4]. Hence, on the nutritional point of view, mung bean is perhaps the best of all other pulses [5]. Due to short duration of mung bean it can fit as a cash crop between major cropping seasons. Mung bean cultivation can advance the physical, biological and chemical properties of soil as well as enhance fertility of soil through nitrogen fixation by symbiotic process with the help of micro-symbionts (Rhizobium) Phosphorus is a key constituent of ATP and it plays a significant role in the energy transformation in plants [6]. And also essential for energy storage and release in living cells. The Zn essentially is being employed in functional and structural component of several enzymes, such as carbonic anhydrase, alcohol dehydrase, alkaline phosphatase, phospholipase, carboxypeptidase and RNA polymerase [7]. Further, plants emerging from seeds with lower $\mathrm{Zn}$ could be highly sensitive to biotic and abiotic stresses [8]. Zn enriched seeds performs better with respect to seed germination, seedling growth and yield of crops [9]. The farmers of Bangladesh generally grow mung bean with almost no fertilizers. Considering the above facts, the present study is aimed at following objectives to determine the effects of phosphorus and Zinc on the growth and yield of mung bean and to study the combine effect of phosphorus and zinc on growth and yield of mungbean [10].

\section{Material and Method}

The experiment was carried out in the Agronomy Research Farm, University of Agriculture Peshawar, Pakistan, during the passé from April to July,2017. BARI mug 6, a great yielding variety of mung bean was taken by National Agricultural Research Institute (NARC). It is photo unaffected, semi synchronous maturity, short lifecycle (60 to 65 days) and bold seeded crop. Its yield potentiality is about $2 \mathrm{t} \mathrm{ha}^{-1}$. BARI mug 6 
variety is much resistant to various viruses' diseases like yellow mosaic virus diseases, insects and pest attack. The plot taken for the experiment was driven by rotavator on the 6th April 2017, after the practice of rotavator the land was ploughed and crossploughed numerous times. The experiment comprised of two factors: Factor A: Phosphorus (P), P0= No P ha1, P1=15 kg P ha-1, $\mathrm{P} 2=20 \mathrm{~kg} \mathrm{P}^{-1}$ and P3= $30 \mathrm{~kg} \mathrm{P} \mathrm{ha}^{-1}$; Factor B: Zinc (Zn), Zn0= No Zn ha ${ }^{-1}, \mathrm{Zn} 1=1.5 \mathrm{~kg} \mathrm{Zn} \mathrm{ha}^{-1}$ and Zn2=4 kg Zn ha-1 12 treatment combinations were arranging from these levels. The experiment was placed in a Randomized Complete Block Design (RCBD) with four replications. The total number of plots was 48 , each sub plot was $2.5 \mathrm{~m} \times 2 \mathrm{~m}$.

Blanket recommended doses of $\mathrm{K}, \mathrm{N}$ and Sulphur (, $30 \mathrm{~kg}$ $\mathrm{K}$ from MoP, $20 \mathrm{~kg} \mathrm{~N}$ from urea and $15 \mathrm{~kg} \mathrm{~S} \mathrm{ha}^{-1}$ from Gypsum, respectively) were applied. The basal dose of whole amounts of MoP, Gypsum and half of total Urea fertilizer were applied during land preparation. The rest of the fertilizer urea was given after 28 days of seed sowing. The required amounts of P (from TSP) and Zn (from Zinc oxide) were applied at a time as per treatment combination after field layout of the experiment and were mixed properly through hand spading. Mung bean seeds were sown on 18th April 2014 in rows following the recommended row to row distance of $30 \mathrm{~cm}$ and plant to plant distance of $10 \mathrm{~cm}$. Various intercultural operations such as thinning of plants, weeding and spraying of insecticides were accomplished whenever required to keep the plants healthy and the field weed free. The crop was harvested at maturity on $29^{\text {th }}$ June 2014 . The harvested crop of each plot was bundled separately. Ten (10) plants from each plot were selected as random and were tagged for the data collection. Data were collected at harvesting stage. The collected data were Table 1: Influence of phosphorous on parameters of growth. analyzed with the help of MSTAT-C program and mean values of all the parameters were adjusted by Least Significant Difference (LSD) at $5 \%$ level of probability [12].

\section{Results and Discussions}

\section{Influence of Phosphorus on Growth and Yield of Mung Bean}

Mung bean plants revealed significant variation in respect of plant height, number of branches plant ${ }^{-1}$, number of pods plant ${ }^{-1}$, number of seeds pod ${ }^{-1}$, Pod length, 1000 seeds weight, seed yield $\left(\mathrm{t} \mathrm{ha}^{-1}\right)$ and stover yield $\left(\mathrm{tha}^{-1}\right)$ when phosphorus application in different dosages were applied (Table 1). Plant height, number of branches plant $t^{-1}$, number of pods plant ${ }^{-1}$, number of seeds $\operatorname{pod}^{-1}$ : Plant height, number of branches plant ${ }^{-1}$, number of pods plant $^{-1}$, number of seeds pod ${ }^{-1}$, Pod length and thousand seeds weight were increased with P levels from $0-20 \mathrm{~kg} \mathrm{ha}^{-1}$. The taller plant $(50.02 \mathrm{~cm})$, number of branches plant ${ }^{-1}$ (2.85), number of pods plant-1 (20.75) and number of seeds pod $^{-1}$ (13.31) were achieved with the application of $20 \mathrm{~kg} \mathrm{P} \mathrm{ha}^{-1}$. On the other hand, the shorter plant $(43.1 \mathrm{~cm})$, number of branches plant ${ }^{-1}(1.78)$, number of pods plant ${ }^{-1}$ (15.03) and number of seeds pod ${ }^{-1}$ (10.40) were observed where no application of phosphorous. The result is approved with the findings of Kumar et al. [13]. Pod length and weight of 1000 -seeds as affected by different doses of phosphorus showed significant variation statistically. Among the different doses of Phosphorous the highest pod length $(9.44 \mathrm{~cm})$ and thousand seeds weight (45.33g) was observed in P2 $(20 \mathrm{~kg} \mathrm{P}$ ha $\left.^{-1}\right)$. The lowest pod length $(7.43 \mathrm{~cm})$ and thousand seeds weight (42.23g) were observed where no phosphorous fertilizers were applied i.e. P0.

\begin{tabular}{|c|c|c|c|c|c|c|c|c|}
\hline $\begin{array}{l}\text { Levels of P } \\
\left(\mathrm{Kg} \mathrm{ha}^{-1}\right)\end{array}$ & $\begin{array}{l}\text { Plant height } \\
\text { (cm) }\end{array}$ & $\begin{array}{c}\text { No. of } \\
\text { branches }^{-1} \\
\text { Plant }^{-1}\end{array}$ & $\begin{array}{l}\text { No. of pods } \\
\text { plant }^{-1}\end{array}$ & $\begin{array}{c}\text { No. of seeds } \\
\text { pod }^{-1}\end{array}$ & $\begin{array}{l}\text { pod length } \\
\text { (cm) }\end{array}$ & $\begin{array}{l}1000 \text { seeds } \\
\text { weight }(\mathrm{g})\end{array}$ & $\begin{array}{c}\text { Seed yield ( } t \\
\text { ha }^{-1} \text { ) }\end{array}$ & Stover yield \\
\hline \multicolumn{9}{|l|}{$\left(\mathrm{t} \mathrm{ha}^{-1}\right)$} \\
\hline $\mathrm{P} 0$ & $43.11 \mathrm{~d}$ & $1.78 \mathrm{~d}$ & $15.03 \mathrm{c}$ & $10.40 \mathrm{c}$ & $7.43 \mathrm{~d}$ & $42.23 \mathrm{c}$ & $2.08 \mathrm{c}$ & \\
\hline $\mathrm{P} 0$ & $47.83 \mathrm{c}$ & $2.44 \mathrm{c}$ & $17.23 \mathrm{~b}$ & $11.43 \mathrm{~b}$ & $8.32 \mathrm{c}$ & $43.87 \mathrm{~b}$ & $1.48 \mathrm{~b}$ & $2.31 \mathrm{~b}$ \\
\hline P0 & $50.02 \mathrm{a}$ & $2.85 \mathrm{a}$ & $20.75 \mathrm{a}$ & $13.31 \mathrm{a}$ & $9.44 \mathrm{a}$ & $45.33 \mathrm{a}$ & $1.54 \mathrm{a}$ & $2.58 \mathrm{a}$ \\
\hline P0 & $48.93 \mathrm{~b}$ & $2.66 \mathrm{~b}$ & $18.97 \mathrm{~b}$ & $10.69 \mathrm{~b}$ & $8.34 \mathrm{~b}$ & $42.17 \mathrm{ab}$ & $1.53 \mathrm{a}$ & $2.59 \mathrm{a}$ \\
\hline LSD (0.05) & 1.22 & 0.071 & 0.76 & 0.48 & 0.44 & 1.18 & 0.069 & 0.082 \\
\hline
\end{tabular}

The result is similar with the outcomes of Kumar et al. [13]. Who detected significant increase in pod length, number of grains $\operatorname{pod}^{-1}, 1000$ seeds weight, seed yield, and Stover yield of mung bean due to the application of increasing level of Phosphorous fertilizer. Seed yield and stover yield was also found significant by different doses of Phosphorous been applied (Tables 1-3). The highest seed yield (1.54 $\left.\mathrm{t} \mathrm{ha}^{-1}\right)$ was recorded in P2 $(20 \mathrm{~kg}$ $\left.\mathrm{P} \mathrm{ha}^{-1}\right)$ but the highest stover yield $\left(2.59 \mathrm{t} \mathrm{ha}^{-1}\right)$ was recorded in
P3 (30 kg P ha ${ }^{-1}$ ) treatment. The lowest seed yield (1.43 $\mathrm{t} \mathrm{ha}^{-1}$ ) and stover yield (2.08 $\mathrm{t} \mathrm{ha}^{-1}$ ) of mung bean was recorded where no phosphorous application was applied i.e. P0. There was no significant difference between P2 and P3 treatments. The result is fixed with the findings of Oad et al. [14] who recorded significant increase in grain yield, and straw yield of mung bean by the application of $100 \mathrm{~kg}$ P fertilizer. 
Table 2: Influence of zinc on parameters of growth.

\begin{tabular}{|c|c|c|c|c|c|c|c|c|}
\hline $\begin{array}{l}\text { Levels of Z } \\
\left.\text { (Kg ha-1 }^{-1}\right)\end{array}$ & $\begin{array}{l}\text { Plant height } \\
\text { (cm) }\end{array}$ & $\begin{array}{c}\text { No. of } \\
\text { branches } \\
\text { Plant }^{-1}\end{array}$ & $\begin{array}{l}\text { No. of pods } \\
\text { plant }^{-1}\end{array}$ & $\begin{array}{l}\text { No. of seeds } \\
\text { pod }^{-1}\end{array}$ & $\begin{array}{l}\text { Pod length } \\
\text { (cm) }\end{array}$ & $\begin{array}{l}1000 \text { seeds } \\
\text { weight }(\mathrm{g})\end{array}$ & $\begin{array}{c}\text { Seed yield ( } t \\
\text { ha }^{-1} \text { ) }\end{array}$ & $\begin{array}{c}\text { Stover yield } \\
\left(\mathrm{t} \mathrm{ha}^{-1}\right)\end{array}$ \\
\hline Zn0 & $46.80 \mathrm{~b}$ & $2.01 \mathrm{c}$ & $15.34 \mathrm{~b}$ & $10.14 \mathrm{~b}$ & $8.04 \mathrm{c}$ & $38.22 \mathrm{~b}$ & $1.38 \mathrm{c}$ & $2.19 \mathrm{~b}$ \\
\hline Zn1 & $48.32 \mathrm{ab}$ & $2.43 \mathrm{~b}$ & $16.43 \mathrm{~b}$ & $10.92 \mathrm{a}$ & $8.78 \mathrm{~b}$ & $40.48 \mathrm{ab}$ & $1.65 \mathrm{~b}$ & $2.30 \mathrm{~b}$ \\
\hline $\mathrm{Zn} 2$ & $50.55 \mathrm{a}$ & $2.54 \mathrm{a}$ & $19.11 \mathrm{a}$ & $11.70 \mathrm{a}$ & $9.43 \mathrm{a}$ & $42.86 \mathrm{a}$ & $1.77 \mathrm{a}$ & $2.77 \mathrm{a}$ \\
\hline LSD (0.05) & 1.22 & 0.09 & 0.82 & 0.53 & 0.76 & 1.96 & 0.06 & 0.06 \\
\hline
\end{tabular}

Table 3: Interactive effect of phosphorous and zinc on yield and yield attributes of mung bean.

\begin{tabular}{|c|c|c|c|c|c|c|c|c|}
\hline $\begin{array}{c}\text { Interaction } \\
\text { of P and Zn }\end{array}$ & $\begin{array}{c}\text { Plant } \\
\text { height(cm) }\end{array}$ & $\begin{array}{c}\text { No. of } \\
\text { branches) } \\
\text { Plant }^{-1}\end{array}$ & $\begin{array}{c}\text { No. of pods } \\
\text { plant }\end{array}$ & $\begin{array}{c}\text { No. of seeds } \\
\text { pod }^{-1}\end{array}$ & $\begin{array}{c}\text { Pod length } \\
\text { (cm) }\end{array}$ & $\begin{array}{c}\text { 1000 seeds } \\
\text { weight (g) }\end{array}$ & $\begin{array}{c}\text { Seed yield (t } \\
\text { ha }^{-1} \text { ) }\end{array}$ & $\begin{array}{c}\text { Stover yield } \\
\text { (t ha-1 }^{-1}\end{array}$ \\
\hline P0Zn0 & $41.55 \mathrm{~h}$ & $1.58 \mathrm{i}$ & $14.06 \mathrm{~g}$ & $8.74 \mathrm{f}$ & $6.43 \mathrm{~g}$ & $38.98 \mathrm{~g}$ & $1.09 \mathrm{~g}$ & $2.06 \mathrm{gh}$ \\
\hline P0Zn1 & $42.17 \mathrm{~h}$ & $2.09 \mathrm{i}$ & $14.65 \mathrm{fg}$ & $9.42 \mathrm{ef}$ & $6.87 \mathrm{fg}$ & $39.67 \mathrm{fg}$ & $1.15 \mathrm{~g}$ & $2.04 \mathrm{~b}$ \\
\hline P0Zn2 & $43.44 \mathrm{~g}$ & $1.98 \mathrm{~h}$ & $15.43 \mathrm{f}$ & $10.30 \mathrm{~cd}$ & $7.12 \mathrm{f}$ & $41.57 \mathrm{de}$ & $1.18 \mathrm{fg}$ & $2.15 \mathrm{fg}$ \\
\hline P1Zn0 & $45.66 \mathrm{f}$ & $2.54 \mathrm{~g}$ & $15.59 \mathrm{f}$ & $9.97 \mathrm{de}$ & $7.27 \mathrm{f}$ & $40.80 \mathrm{ef}$ & $1.20 \mathrm{f}$ & $2.16 \mathrm{fg}$ \\
\hline P1Zn1 & $46.33 \mathrm{e}$ & $2.76 \mathrm{f}$ & $16.64 \mathrm{e}$ & $10.94 \mathrm{bd}$ & $7.28 \mathrm{f}$ & $42.00 \mathrm{ce}$ & $1.30 \mathrm{e}$ & $2.17 \mathrm{f}$ \\
\hline P1Zn2 & $49.32 \mathrm{~d}$ & $2.90 \mathrm{de}$ & $18.54 \mathrm{bc}$ & $11.34 \mathrm{bc}$ & $8.27 \mathrm{e}$ & $43.32 \mathrm{bc}$ & $1.43 \mathrm{~d}$ & $2.42 \mathrm{de}$ \\
\hline P2Zn0 & $49.09 \mathrm{c}$ & $2.79 \mathrm{ef}$ & $17.86 \mathrm{~cd}$ & $10.59 \mathrm{bd}$ & $7.95 \mathrm{e}$ & $42.08 \mathrm{~cd}$ & $1.42 \mathrm{~d}$ & $2.38 \mathrm{e}$ \\
\hline P2Zn1 & $52.21 \mathrm{ab}$ & $3.12 \mathrm{~b}$ & $19.37 \mathrm{~b}$ & $12.95 \mathrm{a}$ & $9.94 \mathrm{~b}$ & $43.25 \mathrm{bc}$ & $1.48 \mathrm{~cd}$ & $2.54 \mathrm{~cd}$ \\
\hline P2Zn2 & $53.45 \mathrm{a}$ & $3.32 \mathrm{a}$ & $20.89 \mathrm{a}$ & $12.98 \mathrm{a}$ & $10.57 \mathrm{a}$ & $45.66 \mathrm{a}$ & $1.94 \mathrm{a}$ & $2.69 \mathrm{~cd}$ \\
\hline P2Zn0 & $49.98 \mathrm{c}$ & $2.79 \mathrm{ef}$ & $17.04 \mathrm{de}$ & $10.58 \mathrm{bd}$ & $8.44 \mathrm{de}$ & $42.07 \mathrm{~cd}$ & $1.42 \mathrm{~d}$ & $2.53 \mathrm{~cd}$ \\
\hline P3Zn1 & $50.39 \mathrm{bc}$ & $2.87 \mathrm{~d}$ & $17.48 \mathrm{ce}$ & $11.03 \mathrm{~b}$ & $8.96 \mathrm{~cd}$ & $43.70 \mathrm{~b}$ & $1.53 \mathrm{bc}$ & $\mathrm{bc} 2.59 \mathrm{bc}$ \\
\hline P3Zn2 & $49.07 \mathrm{c}$ & $2.60 \mathrm{c}$ & $18.46 \mathrm{bc}$ & $10.91 \mathrm{bc}$ & $9.27 \mathrm{c}$ & $43.33 \mathrm{bc}$ & $1.64 \mathrm{~b}$ & $2.68 \mathrm{~b}$ \\
\hline LSD (0.05) & 1.23 & 0.09 & 0.98 & 0.52 & 0.63 & 1.17 & 0.073 & 0.072 \\
\hline
\end{tabular}

\section{Effect of Zinc on Growth and Yield of Mung Bean}

Mung bean crop revealed significant variation for plant height, number of branches plant-1, number of pods plant ${ }^{-1}$, number of seeds pod $^{-1}$, pod length, 1000 seeds weight, seed yield and stover yield different dosages of zinc were applied. Plant height, number of branches plant ${ }^{-1}$, number of pods plant ${ }^{-1}$ and number of seeds pod ${ }^{-1}$. Among zinc fertilizer dosages, Zn2 (4 kg $\left.\mathrm{Zn} \mathrm{ha}^{-1}\right)$ showed the taller plant $(50.55 \mathrm{~cm})$, number of branches plant $^{-1}$ (2.54), number of pods plant ${ }^{-1}$ (19.11) and number of seeds pod $^{-1}$ (11.70). On the divergent, the shorter plant $(46.80$ $\mathrm{cm})$, number of branches plant ${ }^{-1}(2.01)$, number of pods plant ${ }^{-1}$ (15.34) and number of seeds $\operatorname{pod}^{-1}$ (10.14) was noted in the treatment where no application of zinc was practiced. Islam et al. [15] noticed significant increase in plant height, number of branches plant ${ }^{-1}$, number of pods plant ${ }^{-1}$ and number of seeds $\operatorname{pod}^{-1}$ of mung bean due to the application of $0.3 \%-0.6 \% \mathrm{ZnO}$ solution. Among the different $\mathrm{Zn}$ doses, Zn2 (4 kg Zn ha-1) showed the highest pod length $(9.43 \mathrm{~cm})$ and 1000 seeds weight $(42.86 \mathrm{~g})$. On contrary, the lowest pod length $(8.04 \mathrm{~cm})$ and 1000 seeds weight (38.22 g) was noted where no application of zinc practiced i.e. Zn0. Islam et al. [15] recorded significant increase in length of pod of mung bean due to the application of $0.3 \%$ $0.6 \% \mathrm{ZnO}$ solution. Among the zinc fertilizer dosages, $\mathrm{Zn} 2$ (4 kg $\left.\mathrm{Zn} \mathrm{ha}^{-1}\right)$ gave the highest seed yield $\left(1.77 \mathrm{t} \mathrm{ha}^{-1}\right)$ and stover yield
( $2.77 \mathrm{t} \mathrm{ha}^{-1}$ ) of mung bean. On the other hand, the lowest seed yield (1.38 t ha-1) and stover yield (2.19 $\mathrm{t} \mathrm{ha}^{-1}$ ) of mung bean were found in $\mathrm{Zn} 0$ where no $\mathrm{Zn}$ fertilizer was applied. $\mathrm{Zn} 1$ and $\mathrm{Zn} 2$ were statistically similar in case of stover yield.

\section{Interactive Effect of Phosphorous and Zinc on Yield and Yield Attributes of Mung Bean}

Mutual application of dosages of phosphorus and zinc revealed significant effect on the plant height, number of branches plant ${ }^{-1}$, number of pods plant ${ }^{-1}$, number of seeds pod ${ }^{-1}$, pod length, thousand seeds weight, seed yield and stover yield of mung bean. The shorter plant $(41.55 \mathrm{~cm})$, number of branches plant $^{-1}$ (1.58), number of pods plant ${ }^{-1}(14.06)$ and number of seeds pod $^{-1}$ (8.74) were observed where no phosphorous and zinc application applied i.e. P0Zn0. On the contrary the taller plant $(53.45 \mathrm{~cm})$, number of branches plant ${ }^{-1}$ (3.32), number of SSpods plant ${ }^{-1}$ (20.89) and number of seeds pod-1 (12.98) were noted in P2Zn2 (20 kg P ha-1 $\left.+4 \mathrm{~kg} \mathrm{Zn} \mathrm{ha}^{-1}\right)$ treatment combination. Ahmed et al. [16] recorded significant increase in plant height, number of branches plant ${ }^{-1}$, number of pods plant ${ }^{-1}$ and number of seeds pod ${ }^{-1}$ of mung bean due to the increasing application level of $\mathrm{P}$ and $\mathrm{Zn}$. The highest pod length $(10.57 \mathrm{~cm})$ and thousand seeds weight (45.66g) were noticed in P2Zn2 (20 $\mathrm{kg} \mathrm{P} \mathrm{ha}{ }^{-1}+4 \mathrm{~kg} \mathrm{Zn} \mathrm{ha}^{-1}$ ) treatment combination. On the divergent, the lowest pod length $(6.43 \mathrm{~cm})$ and 1000 seeds weight $(38.98 \mathrm{~g})$ 
were noted in P0Zn0. Singh et al. [17] recorded significant increase in pod length and thousand seeds weight of mung bean due to the increasing application levels of $\mathrm{P}$ fertilizer. The highest seed yield (1.94 t ha-1) and stover yield (2.69 $\mathrm{t} \mathrm{ha}^{-1}$ ) of mung bean were verified with the treatment combination of P2Zn2 $20 \mathrm{~kg}$ $\left.\mathrm{P} \mathrm{ha}^{-1}+4 \mathrm{~kg} \mathrm{Zn} \mathrm{ha}^{-1}\right)$. On the other hand, the lowest seed yield (1.09 $\left.\mathrm{t} \mathrm{ha}^{-1}\right)$ and stover yield (2.06 $\left.\mathrm{t} \mathrm{ha}^{-1}\right)$ of mung bean were recorded in P0Zn0 and P0Zn1 (No P and 1.5kg Zn) treatment combinations, respectively. Singh and Bajpai [18] found that P and $\mathrm{Zn}$ enhance significantly the grain as well as stover yields of chickpea.

\section{Conclusion}

On the Basis of the results of the present findings, the following recommendation may be considered - Application of Phosphorus and Zinc fertilizers @ 20 kg P ha ${ }^{-1}$ and $4 \mathrm{~kg} \mathrm{Zn} \mathrm{ha}^{-1}$ may be the finest combination for higher yield of mung bean and also to conserve soil fertility and productivity than their individual application.

\section{References}

1. Ahmed AU, S Rahman, Begum, NMS Islam (1986) Effect of phosphorus and zinc apptication on the growth, yield and P, Zn and protein content of mung bean. J Indian Soc Soil Sci 34(2): 305-308.

2. BARI (1998) Mung bean Cultivation in Bangladesh. A booklet in Bengali. Bangladesh Agril Res Ins Joydebpur, Gazipur.

3. BBS (2010) Statistical Year Book of Bangladesh. Statistics Division, Ministry of Planning, Government of the Peoples Republic of Bangladesh, Dhaka. pp. 64-79.

4. Cakmak I, B Torun, B Erenoglu, M Kalayci, A Yilmaz, et al. (1996) Zinc deficiency in soils and plants in Turkey and plant mechanism involved in Zinc deficiency, Turk. J Agric p. 13- 23.

5. Coleman JE (1991) Zinc proteins: Enzymes, storage proteins, transcription factors and Replication Proteins. Ann Rev Biochem 61: 897-946.
6. Frauque A, T Haraguchi, O Hirota, MA Rahman (2000) Growth analysis, yield, and canopy structure in maize, mung bean intercropping. $\mathrm{Bu}$. Inst. of Tropical Agric. Kyushu University Fukuoka, Japan 23: 61-69.

7. Gomez KA, AA Gomez (1984) Statistical Procedures for Agricultural Research ( $2^{\text {nd }}$ Edn.); John Willey and Sons, Singapore, pp. 2892.

8. Haider HM, F Ahmad, F Mushtaq (1991) Role of physio-morphic characters imparting resistance in cotton against some insect pests. Pak Entomol 21: 61-66.

9. Islam MS, MSU Bhuiyan, MG Miah (1989) Effect of zinc on lentil yield and yield components. Lens-Newsletter 16(1): 30-32.

10. Kaul AK (1982) Pulses in Bangladesh BARC, Farm Gate. Dhaka p. 27

11. Khan MRI (1981) Nutritional quality characters in pulses. In Proc MAT Workshop Pulses, pp. 199 -206.

12. Kumar R, YV Singh, S Singh, AM Latare, PK Mishra, et al. (2012) Effect of phosphorus and sulphur nutrition on yield attributes, yield of mung bean (Vigna radiata L. Wilczek). J Chem and Pharma Res 4(5): 25712573.

13. Obata H, S Kawamura, K Senoo, A Tanaka (1999) Changes in the level of protein and activity of $\mathrm{Cu} / \mathrm{Zn}$ Superoxide dismutase in Zinc deficient rice plants Oryza savita L. Soil Sci Plant Nutr 45: 891-896.

14. Oad FC, AN Shah, GH Jamro, SH Ghaloo (2003) Phosphorus and potassium requirements of mung bean (Vigna radiata). J Applied Sci 3(6): 428-431.

15. Romheld, H Marschner (1991) Function of micronutrients in plants. Micronutrients in Agriculture, In JJ Mortvedt, FR Cox, LM Shuman, RM Welch (Eds.), Soil Science Society of America, Madison pp. 297-328.

16. Sangakara UR, M Frehner, N Nosberger (2001) Influence of soil moisture and potassium fertilizer the vegetative growth of mung bean (Vigna radiata L.). J Agron Crop Sci 186(2): 73-81.

17. Singh AP, RK Chaudhur, RPR Sharma (1993) Effect of inoculation and fertilizer levels on yield, nutrient uptake and economics of summer pulses. J Potassium Res 90: 176-178.

18. Singh G, MR Bajpai (1982) Response of Chikpea to P and foliar application of Zinc and sulphuric acid. Indian Agric Sci 52(12): 835837.

\section{Your next submission with Juniper Publishers will reach you the below assets}

- Quality Editorial service

- Swift Peer Review

- Reprints availability

- E-prints Service

- Manuscript Podcast for convenient understanding

- Global attainment for your research

- Manuscript accessibility in different formats

(Pdf, E-pub, Full Text, Audio)

- Unceasing customer service

Track the below URL for one-step submission https://juniperpublishers.com/online-submission.php 